\section{Bożena Frączek}

https://orcid.org/0000-0003-0031-7801

Department of Banking

and Financial Markets

Faculty of Finance and Insurance

University of Economics in Katowice,

Katowice, Poland

b.fraczek@ue.katowice.pl

\section{Piotr Dąbrowski}

https://orcid.org/0000-0002-9151-6138

Department of Banking

and Financial Markets

Faculty of Finance and Insurance

University of Economics in Katowice,

Katowice, Poland

piotr.dabrowski@ue.katowice.pl

\title{
The preferences in capital allocation among economics students in Poland. Investments on the Warsaw Stock Exchange and forex in comparison to a poker game
}

Accepted by Editor Ewa Ziemba | Received: April 3, 2019 | Revised: July 10, 2019; September 23, 2019; October 11, 2019 | Accepted: October 18, 2019.

\begin{abstract}
Aim/purpose - The paper examines the level of investment activity among the last semester master's degree students of economics fields, including investment in stocks and in forex $(\mathrm{FX})$ in comparison to a poker game.

Design/methodology/approach - The paper presents the exploration of similarities and differences of stock trading, forex trading and poker playing (a critical analysis of the literature), and questionnaire research among 613 students of the last semester of studies at the University of Economics in Katowice.

Findings - A decreasing level of a participation of individuals in financial markets refers to different financial segments like capital markets and trading on, e.g. the Warsaw Stock Exchange (WSE) or the foreign exchange market (forex, FX). The current market situation does not constitute favourable conditions to increase commitment of individual investors on the WSE. In addition, other form of investment among young people is being observed, e.g. poker. The results of the research stress the role of an effective financial education and its influence on a changing the attitudes towards investments.

Research implications/limitations - The research sample is limited to the students of one university.

Originality/value/contribution - So far, there has not been conducted any research among potential important participants of financial markets which takes into account the listed alternatives: investments on the Warsaw Stock Exchange and in forex, or a poker game.
\end{abstract}

Cite as: Frączek, B., \& Dąbrowski, P. (2019). The preferences in capital allocation among economics students in Poland. Investments on the Warsaw Stock Exchange and forex in comparison to a poker game. Journal of Economics \& Management, 38(4), 67-88. https://doi.org/ 10.22367/jem.2019.38.04 
Keywords: financial investment, stock exchange, forex (FX), poker game, trading. JEL Classification: G11, G23, G40, I22.

\section{Introduction}

For many years, especially in the trading segment of the capital market, the diminishing participation of individual investors has been noticed on the financial markets (Australian Securities Exchange, 2012; Evans, 2016; Hong Kong Exchanges and Clearing Limited, 2015; WSE, 2018). Due to the importance of individuals for the functioning and development of the market - as capital, liquidity and volatility suppliers - it is not a positive trend. On the one hand, as the research shows, economists are more likely to hold stocks than other investors (Christiansen, Joensen, \& Rangvid, 2008). But on the other, the authors of this paper observe the lack of interest in stock trading in the group of students who study economics. However, their special role as future economists and financiers for the financial market should not be neglected. Not only do they represent the potential as the future participants of financial markets, but also as their future creators, advisors and analysts who are important for market development.

The decreasing level of the participation in financial markets refers to different financial segments like capital markets and trading on, e.g. the Warsaw Stock Exchange (WSE) or the forex. Moreover, other forms of 'earning money' among young people, e.g. poker, are observed (DiCicco-Bloom \& Romer, 2012; Kim, Wohl, Gupta, \& Derevensky, 2017). That is why, it is worth examining the level of an investment activity among the last semester master's degree students of economics fields as the potential active participants of financial markets, including an investment in stocks and an investment in forex in comparison to a poker game.

Although there are many similarities (mainly due to a financial risk) between the investment in financial market instruments and a gambling, these two concepts are fundamentally different. This is the fact that certain stock market activities can be commonly identified as gambling-like within the financial sector, and conversely, the gambling participation sometimes includes high-risk activities which is similar to speculative investments in stocks, and/or a day trading. In addition, the population surveys of a gambling participation sometimes include questions about high-risk stocks and other forms of speculative investments. Furthermore, different forms of gambling are increasingly used instead of investment (mainly speculative). 
This paper is arranged into five parts. The first section presents the introductory aspect of the study. It should be emphasised that such research has never been conducted yet. The second section deals with the literature review. This part intends to present the characteristics of an investment on the stock exchange, in forex and features of a poker game. The third section provides the methodology of the research, while the fourth section presents the research findings and discussion. The conclusions are drawn in the last section.

\section{Literature review}

There are many factors affecting the scale and the range of participation in particular forms of investing. The results of much research confirm the impact of many different socio-demographic factors, for instance: age, education, income, wealth, employment status and occupation, stages in the life cycle and marital status (Aren \& Aydemir, 2015; Barasinska \& Schäfer, 2018; Kumari, Satya, \& Kritika, 2018). The conducted research also confirms that an investment objective and an asset familiarity play a vital role in the choice of elements of the investment portfolio (Seetharaman, Niranjan, Patwa, \& Kejriwal, 2017). After the financial crisis, the literature more and more often refers to an additional category of factors, namely psychographic variables (Geetha \& Vimala, 2014; Kiran \& Rao, 2005), personality traits, behavioural biases, sentiment and others, like social interactions and media (Goodfellow \& Gebka, 2009; Kourtidis, Sevic, \& Chatzoglou, 2011; Nguyen \& Bhatti, 2015).

These factors determine the attitude towards a risk, investment result expectations as well as the investment, a trading behaviour (Shanmugham \& Ramya, 2012). Moreover, the analysis of factors does not omit the impact of a financial literacy and a high experience in an investment decision- and choice-making (Lodhi, 2014). Ultimately, the wealth-maximisation criteria usually seem to be the most important (Nagy \& Obenberger,1994/reprints 2018; Obamuyi, 2013).

Thus, there is no single factor that influences investment decisions of an individual. Moreover, factors influencing investment decision vary from time to time, place to place, person to person, securities to securities etc. (Aruna \& Rajashekar, 2016). Considering the factors regarding the particular forms of risky investment (because investors have a wide range of risky financial offers, e.g. stocks) the attention should be paid to: investors' tolerance for risk, a strength of the economy, media focus on the stock market, a political stability and a government policy towards a business as the most important factors influencing the 
investments in stocks (Bennet, Selvam, Indhumathi, Ramkumar, \& Karpagam, 2011; Joshi \& Batra, 2017). Each form of an investment has its pros and cons, its strengths and weaknesses, which together with personality traits of investors create an own individual complex of factors for almost each investor. That is why, it is very difficult to forecast the future investment preferences and a behaviour of individual investors.

The financial crisis has revealed many weak points of financial markets. One of them is the lack of a durability of ties connecting individual investors with the capital market. The participation of individuals in the financial markets is essential - they engage their assets in investments, transfer a capital to companies, provide a liquidity to different financial instruments and affect the volatility. Their sentiment strongly affects the behaviour of the listed stocks and the stock exchange (Baker \& Wurgler, 2007). Despite their image of being less informed, less aware and less educated investors, their impact on the market cannot be neglected.

Regardless of the possibilities of offers with the high return, the participation of individual investors in the stock market is limited. One of the most important reasons for a reduced engagement of individual investors in trading is a loss of a confidence in the financial markets, especially in more risky segments. However, it should be pointed out that a decreasing interest in trading has already been visible before the financial crisis. In Australia, 52\% of the population was investing in stocks in 2000 and it diminished to 38\% in 2012 (Australian Securities Exchange, 2012), and 37\% in 2017 (Deloitte Access Economics, 2017). In the USA, the shrinking participation of individuals has been noticed since 1950, when $90 \%$ of American stocks were held by individuals and they held only $30 \%$ of the stocks in 2009. Moreover, based on the NYSE (New York Stock Exchange) data, individuals generate barely $2 \%$ of the turnover (Evans, 2016). Naturally, there are some exceptions where participation of the individual investors increases. In 2017, close to half (48\%) the Hong Kong retail investors invested in stocks (Investor Education Centre, 2017). In Hong Kong, 36.7\% of individuals had stocks and derivatives listed on HKEx in their portfolios in 2014 (Hong Kong Exchanges and Clearing Limited, 2015) and in the years 2011, 2009, 2007, $2005,2004,2000$ it was: $35.8 \%, 35.1 \%, 35.7 \%, 28.8 \%, 24.6 \%, 21 \%$, respectively (Hong Kong in Surveys, 2000, 2004, 2005, 2007, 2009, 2010).

In Poland, the participation of individual investors on the WSE has been decreasing steadily from year to year. In 2002, 29\% of the total turnover of the WSE was generated by individuals and it was 13\% in 2016, 14\% in 2017 and 
only $12 \%$ in 2018 . As for the futures contracts, individuals generated $79 \%$ of total turnover in 2002 and $51 \%$ in 2017, similar to the options market $-73 \%$ in 2003 and 46\% in 2017 (WSE, 2018). The current market situation does not constitute favourable conditions for increasing the commitment of individual investors on the WSE. It is the result of the unsatisfactory (deteriorating) efficiency and investment attractiveness of the domestic stock exchange in comparison to other (foreign) stock markets (Bartkiewicz \& Lęcki, 2015). The one of the reasons for this situation is the low rate of a financial literacy of Polish society and no firm actions in the area of a formal financial education. It concerns both a preliminary financial education of the Polish society, as well as a university financial education (Frączek, 2016). Additionally, there were cases of violations of investors' rights (Wierzbicka, 2016).

It should be also stressed that the investors' sentiment to the financial markets has strongly differentiated in the last few years. In many countries, e.g. in North America, Western Europe and the developed countries of Asia, the investors' sentiment has improved since 2013 (CFA Institute, 2016). Many individual investors have turned back to the stock trading and the indices have achieved historical top values. The Polish investors' sentiment is still unsatisfactory. The decreasing popularity of investments on the WSE is driven by a general low market prosperity and outcomes of the companies that have been performing below expectations. For a few years, the indices of the WSE have had the poorest performance among European markets.

The mentioned insights are rationales to rethink the alternatives regarding investments/earning money. The investment in forex and a poker game were taken into account. This, in turn, requires the exploration of similarities and differences of stock trading, forex trading and poker playing.

\section{Stock vs. forex trading}

A stock trading and a forex trading share many similarities, although there are even more differences. The main differences result from the features of the capital and currency markets, e.g. types of financial instruments, different aims of trading, timeframes, as well as microeconomic analysis of the stock market against macroeconomic analysis of the forex market.

In practice, typical speculative deals - buying and selling at different prices to benefit from price difference - do not take into account the above-mentioned features. Naturally, investment specialisation in a sector or dividend strategies 
impose upon the trader the focus on capital market (stocks) only. Nevertheless, in any other trading approach, the investor requires from the market the following features:

1) a satisfactory turnover and a liquidity,

2) a diverse offer of financial instruments that are independent of the current market trend or an economic situation,

3) low commissions and other costs of trading and a data access,

4) a functional and user-friendly trading platform with an advanced analytical tools,

5) a leverage.

While comparing the stock market to the forex market one has to take into consideration a great diversification of the capital market. For example, highly-developed huge American, Japan or West-European stock exchanges can easily compete with the forex market when considering the above-listed features. However, by taking into account smaller markets, like the WSE, it is hard to find any advantages and incentives that outperform the foreign markets.

Today, forex is the only segment of the financial market that continuously grows - FX turnover is higher and higher by 70x1012 USD every year. Daily turnover exceeds 5x1012 USD (1.2x1015 USD yearly) (Bank for International Settlements, 2016) which is higher than the cumulated daily turnover of all US stock exchanges and 100 times higher than the yearly turnover of the WSE. A high turnover means a high liquidity, which is, in the majority of cases, sufficient for individuals, prevents slippages and impedes price manipulations.

On the stock exchanges, not only are stocks available to trade, but also bonds, ETFs and derivatives. There are always some instruments that are not correlated with indices and provide independence from main trends. Additionally, apart from the price differences, they allow earning through interest or dividends which makes a long-term investment even more attractive. Moreover, short-selling stocks provide profits on a bear market. A short position is an immanent part of currencies and derivatives, and stocks need borrowing procedures. However, short-selling of stocks on markets is fully automated and practically unnoticeable for the investor today.

The commission is a parameter that directly affects the financial result of every transaction. Forex and the developed US and West-EU stock exchanges usually offer a very attractive level of this kind of cost, as a percentage value of the deal or a fixed rate. Unfortunately, the smaller exchanges, like the WSE, stand out from the global competitors - enormous commissions impede the in- 
vestors' activity in short-term intervals and force them to leave small markets and transfer their accounts to other markets where commissions are at a decent level (Dąbrowski, 2014). The only positive feature of the cost policy of the WSE is the low cost of a data access (quotes and a historical data), which is commonly free of charge and offers a high quality.

The most comfortable access to the market is offered by forex brokers. The trading platforms are easy-to-use, functional, customisable and include many sophisticated analytical tools. All of that is offered for free. On the WSE, as well as on other stock exchanges (including well-developed markets), the trading platforms with quality and usability at the level similar to the forex market, are highly charged and usually need additional integration of an analytical environment with an order module.

Another important aspect of trading for many individual investors is a leverage. Leveraged markets (or instruments) accelerate the volatility of the portfolio at a certain level of the volatility of the price. On the stock exchanges, leverage offered is commonly as high as 10:1 even for non-intraday transactions (however on the WSE for intraday trading only) and on the forex market, the standard is 100:1. Naturally, the higher leverage is, the higher the risk is, and it can be dangerous for the portfolios of inexperienced investors.

Moreover, the conducted research confirmed the interrelationship between a currency market volatility and a stock market volatility, and that the volatility shocks between the stock market and currency market are quite persistent (Aravind, 2017).

The characteristics of the presented financial market segments may be used in many investment strategies and create abundant trading opportunities for the investors irrespective of whether the return of one market is moving up or down.

\section{Poker game vs. investment}

Poker is a card game which was created in the United States in the 1820s (Moreau \& Chabrol, 2016) and is the most popular card game in the world (Loon, Assem, \& Dolder, 2015). In short words, this is a game where from two to 10 players are dealt cards, and where they bet on who has 'the best hand'. There are many variants (e.g. an Eight-Card Poker or Texas' Holdem) and forms of poker games (e.g. a cash game and tournaments as well as a real-life poker variant and an on-line poker). Different types of poker players are specified. Taking into account the skill criterion, the following players can be distin- 
guished as: professionals - highly skilled players, and recreational players - not highly skilled players. In turn, according to the intention criterion, some players play for money (usually regular), while others play for fun (either cash game poker or tournament poker). In poker, it is essential to model the opponents before making a decision (Felix \& Reis, 2008a; Félix \& Reis, 2008b).

There is still a question of whether poker should be considered as a game of skill or a game of chance. On the one hand, research shows that a poker should be regarded as a game of chance (Meyer, Meduna, Brosowski, \& Hayer, 2012), but on the other, the literature demonstrates the results of research that confirm the role of skills in poker (Levitt \& Miles, 2011). These findings are the rationale behind considering a poker game and an investment as alternative activities.

Some authors claim, that finance, especially investments of the highest risk, is a kind of gambling (Arthur, Williams, \& Delfabbro, 2016; Brown, 2006; Jadlow \& Mowen, 2010). Many analogies can be drawn, primarily the risk, while comparing finance to gambling, including poker. A professional trading, as well as, a professional gambling is a risk-taking game, not risk-avoiding. The results of conducted research show that gambling risk-taking propensity helps explain investors' trading activity, especially the popular idea of day traders being 'gamblers' for at least part of the trading population (Markiewicz \& Weber, 2013). In both cases (an investment and a gambling), an active attitude to the risk is needed, additionally supported by adequate knowledge and skills (Levitt $\&$ Miles, 2014), experience and consciousness. In both processes, professionals and non-professionals (recreational players/investors) may be specified (Hunter $\&$ Griffiths, 2012). Investments in stocks and derivatives need data collection, analysis and proper interpretation, which lead to the development of different scenarios. However, conscious interpretation based on an appropriate decisionmaking process does not guarantee positive results. The whole process is similar to a poker.

A poker and a trading have the same psychological plane (making decisions under strong pressure of time and a risk). Both a poker and a trading are strongly influenced by the behavioural aspects of psychology; however, a poker is mostly focused on individuals, while a trading also takes into consideration the influence of the behaviour of the other participants.

Both a trading and a gambling are practiced on the Internet and may be characterised by a high event frequency and a short event duration. The payout intervals may be short, and winnings can be re-invested immediately, which reinforces addictive-like behaviour. Financial losses facilitate re-investing to 
chase losses, and then encourage investors/traders to choose to trade with a high payout ratio, which usually means a higher risk. Sometimes, however, traders/gamblers earn large amounts of money. The wins increase the traders' belief that they have skills to 'feel' and 'control' the stock markets/situations (Grall-Bronnecab et al., 2017).

Buying stocks, currencies or derivatives, as well as playing a poker, is a kind of a bet against other people that concerns a future price behaviour. Both sides, long and short, have the opposite expectations and there can only be one winner.

An ability to make decisions under pressure, control emotions, decrease the impact of psyche on decisions is the next common area of a trading and a gambling (Palomäki, 2013: 44-73).

Naturally, there are as many differences as similarities between a trading and a poker. The investments are fulfilled in the open economic loop, where money flows from and to the capital market or from one instrument to another (e.g. from stocks to bonds). None of the forecasts guarantees the profits, as the final financial results depend on supply and demand, which are unpredictable. Moreover, the number of traders is unknown and unstable. In a poker, the profits depend on stakes. The entry fee is always divided among the players. The expected revenue is always fulfilled in the closed-loop of the known number of players.

Apart from the price differences, the financial market offers other types of rewards - an interest or dividends. It means that money can come from the other investors as well as from the issuer (companies, the state). There is no dividend in poker and the only source of profit is the other players' money.

The investors' decisions are usually made based on the forming trend and the investor searches the optimised moment of placing the opening and closing orders. This means that the investment effectiveness depends on the market situation which is independent of the traders. In poker, the game situation more solely dependents on the players.

It is worth mentioning under current regulations, that a poker played on the Internet is prohibited because it is treated rather as gambling and not as an intellectual strategic game strongly connected with the psychology. In 2016, the Polish Parliament considered introducing amendments to the gambling regulations in the nearest future. The planned change was to refer to the liberalisation of poker and allow playing outside the casinos. However, the majority of the gambling games were planned to be monopolised by the state and the possibilities of playing on the Internet would still be strongly limited. Unfortunately, until now - March 2019 - no changes have 
been implemented. The liberalisation of a gambling can make this type of an activity more competitive to the financial markets and lead to investors' transfers from the stock exchanges to the poker rooms.

In the literature, gambling addictions, especially among youths, are recently more often identified and described. The expanding branch of a gambling with the latest technologies reaches new customers via the Internet more easily than ever before. Young generations, accustomed to video games, computers and the Internet, are the lucrative target for the game providers, including e-casinos (Männikkö, 2017). Today, a gambling is considered as entertainment which allows earning a lot in a really short time (Messerlian, Byrne, \& Derevensky, 2004).

The summary of considerations on investing and playing a poker conducted on the basis of the literature review is presented in Table 1.

Table 1. Summarising characteristics of an investment on the WSE and the forex and a possibility of earning money in a poker game

\begin{tabular}{|c|c|c|c|}
\hline Criterion & Investing in stocks (WSE) & Investing in forex & Poker game \\
\hline 1 & 2 & 3 & 4 \\
\hline $\begin{array}{l}\text { Characteristics } \\
\text { as an investment/ } \\
\text { non-investment }\end{array}$ & $\begin{array}{l}\text { Possibility of investment. } \\
\text { Components: building } \\
\text { productive capacity } \\
\text { and profiting off of risk }\end{array}$ & $\begin{array}{l}\text { Possibility of investment. } \\
\text { Components: facilitating } \\
\text { international trade and profiting } \\
\text { off of risk }\end{array}$ & \begin{tabular}{|l|} 
It is not an investment. \\
It is a transfer between players \\
and it does not add to \\
productive capacity. \\
Components: entertainment \\
and profiting off of risk
\end{tabular} \\
\hline Advantages & $\begin{array}{l}\text { Many stocks and other finan- } \\
\text { cial instruments } \\
\text { Legal and regulated market } \\
\text { Possibility of making big } \\
\text { profits } \\
\text { Investors own a share of the } \\
\text { underlying company and } \\
\text { some companies reimburse } \\
\text { them for their ownership, } \\
\text { in the form of dividends } \\
\text { A relatively easy form } \\
\text { of investing on the stock } \\
\text { exchange }\end{array}$ & $\begin{array}{l}\text { A big number of trading } \\
\text { options (hundreds of currency } \\
\text { pairs, spot and futures trading } \\
\text { etc.) } \\
\text { Legality of actions } \\
\text { Possibility of making big } \\
\text { profits } \\
\text { Investors own currency (the } \\
\text { most liquid form of capital) } \\
\text { 24/7 availability, the ability } \\
\text { to dealing } \\
\text { Unstandardised contracts } \\
\text { (e.g. number of instruments in } \\
\text { contracts) }\end{array}$ & $\begin{array}{l}\text { Many forms of playing (cash } \\
\text { playing, tournaments, playing } \\
\text { via the Internet) } \\
\text { Possibility of earning money } \\
\text { and having a fun } \\
\text { Possibility of achieving the } \\
\text { fame and fortune (mainly } \\
\text { in case of participating and } \\
\text { winning the poker } \\
\text { tournaments) } \\
\text { Independence from the } \\
\text { economic situation }\end{array}$ \\
\hline
\end{tabular}


Table 1 cont.

\begin{tabular}{|c|c|c|c|}
\hline 1 & 2 & 3 & 4 \\
\hline & $\begin{array}{l}\text { Investor Protection - in the } \\
\text { form of strict regulatory } \\
\text { requirements concerning } \\
\text { financial reporting, corporate } \\
\text { governance and disclosure } \\
\text { Secure Clearing usually in the } \\
\text { form of a reliable and secure } \\
\text { clearing mechanism }\end{array}$ & $\begin{array}{l}\text { A lot of flexibility - lack of } \\
\text { restriction on the amount } \\
\text { of money that can be used } \\
\text { for trading } \\
\text { Low transaction costs as } \\
\text { compared to other markets } \\
\text { (e.g. stock exchange) }\end{array}$ & $\begin{array}{l}\text { Moreover - in the case of } \\
\text { online poker: high game } \\
\text { speed, } 24 / 7 \text { availability, } \\
\text { the ability to play at multiple } \\
\text { tables, the absence of travel } \\
\text { costs and 'lighted' cards }\end{array}$ \\
\hline Disadvantages & $\begin{array}{l}\text { Dependence on the economic } \\
\text { situation, a market sentiment, } \\
\text { developments in particular } \\
\text { sectors } \\
\text { Risk due to market } \\
\text { fluctuations - stocks are } \\
\text { volatile investments } \\
\text { Limited access due to the } \\
\text { working hours of the stock } \\
\text { exchange } \\
\text { Standardised contracts (e.g. } \\
\text { number of instruments in } \\
\text { contracts) }\end{array}$ & $\begin{array}{l}\text { Dependence on the economic } \\
\text { conditions and a market } \\
\text { sentiment, an inflation in } \\
\text { particular countries } \\
\text { Risk due to market fluctuations } \\
\text { - currencies are volatile } \\
\text { investments } \\
\text { Higher counterparty risks, } \\
\text { leverage risk and operational } \\
\text { risks in comparison to the stock } \\
\text { exchange market }\end{array}$ & $\begin{array}{l}\text { Too high variance (risk) } \\
\text { Time-consuming } \\
\text { Big bankroll requirements } \\
\text { (financial support, the money } \\
\text { that a player has to possess) - } \\
\text { in the case of tournaments } \\
\text { Limited participation in } \\
\text { a poker in case of tournaments } \\
\text { Lack of underlying assets } \\
\text { owning - poker players have } \\
\text { nothing } \\
\text { Illegality - in many countries }\end{array}$ \\
\hline $\begin{array}{l}\text { Examples of } \\
\text { financial effects }\end{array}$ & $\begin{array}{l}\text { Annual returns of the main } \\
\text { indices on the WSE (calculated } \\
\text { on the data from stooq.pl) } \\
\text { WIG } \\
20140.26 \% \\
2015-9.62 \% \\
201611.38 \% \\
201723.17 \% \\
2018-9.5 \% \\
\text { WIG } 20 \\
2014-3.54 \% \\
2015-19.72 \% \\
20164.77 \% \\
201726.35 \% \\
2018-7.5 \% \\
\text { NCIndex } \\
2014-20.67 \% \\
2015-4.13 \% \\
201610.11 \% \\
2017-9.23 \% \\
2018-28.57 \%\end{array}$ & $\begin{array}{l}\text { Percentage of traders with } \\
\text { a profit and loss on account } \\
\text { by KNF - Polish Financial } \\
\text { Supervision Authority: } \\
\text { Year profit/loss } \\
201420 \% / 80 \% \\
201517.8 \% / 82.2 \% \\
201620.7 \% / 79.3 \% \\
201720.3 \% / 79.7 \% \\
201821.1 \% / 78.9 \% \\
\text { Average total results (profits } \\
\text { and losses) per forex client by } \\
\text { KNF-Polish Financial } \\
\text { Supervision Authority in local } \\
\text { currency (PLN): } \\
\text { Year } \\
2014-12617 \\
2015-13404 \\
2016-10060 \\
2017-12156 \\
2018-10040\end{array}$ & $\begin{array}{l}\text { ROI of 'skilled' and' } \\
\text { unskilled' players in all } \\
\text { tournaments of the } 2010 \\
\text { World Series of Poker: } \\
-7.5 \% \text { - all players } \\
-15.6 \% \text { - not 'high skill' } \\
\text { players } \\
\text { 30.5\% - 'high skill' Players } \\
\text { ROI of 'skilled' and' } \\
\text { unskilled' players in all } \\
\text { tournaments of the } 2010 \\
\text { World Series of Poker with } \\
\text { exclusion of the Main Event } \\
\text { of the } 2010 \text { World Series } \\
\text { of Poker: } \\
-8.3 \% \text { - all players } \\
-13.8 \% \text { - not 'high skill' } \\
\text { players } \\
9.8 \% \text { - 'high skill' players }\end{array}$ \\
\hline
\end{tabular}

Source: Levitt \& Miles (2011); KNF - Polish Financial Supervision Authority (s.a.); Financial portal Stooq.pl (s.a.). 


\section{Research methodology}

What are the perspectives of trading realised by the Polish individual investors on the WSE? This question inspired us to examine the possibilities of using intellectual and capital resources of the students of economics in the investments on the WSE and alternatives. The choice of the research sample (students of the University of Economics in Katowice) was inspired by the previous research (Frączek, Bobenič Hintošová, Bačová, \& Siviček, 2017) ${ }^{1}$ where the potential of young and well-educated in finance people was proved. It indicated that $68 \%$ of young people (18-25 years old) have savings in formal financial institutions (by comparison: in the group of $15+$ years old people, only $21 \%$ have some savings in formal financial institutions). Although the values of the savings are not high, it is worth emphasising that there is a common habit to make savings. Further, the higher the education level is, the greater the sum of savings accumulated. These facts mobilised us to carry out research among students. Moreover, the choice of the students of economics (i.e. economics, management and finance) is justifiable because of their interests and profile that is probably best suited to the financial markets. The area of the research comes from the literature review as well as from pilot studies.

The hypotheses are as follows:

H1: The economics students do not use entirely their intellectual and capital potential in investments on the capital market.

H2: The considerable alternative to the financial market investments is forex trading and poker.

The main aim of this paper is to verify the hypotheses among the students of economics fields and who are at the end of the formal financial education (students of a master's degree last semester). A real and potential activity on different markets and the possibility of their capital investment - WSE, FX and a poker - are taken into account.

An introductory analysis of the literature, observations and conversations with students about their interest in investment were followed by research questionnaire preparation. The authors of this paper have noticed that the areas of interest include: stock trading WSE, forex trading and poker.

Therefore, the questionnaire research was conducted among the students of the last semester of studies at the University of Economics in Katowice. All the students of the last semester were investigated during classes and lectures. The

1 The research was conducted in 2015. 
researchers received 613 completed questionnaires. The University of Economics in Katowice is a typical state university, where students-respondents are characterised by a big number of similar characteristics, including the structure of gender, differences in the size of their home city and differences in their parents' background in economics or lack thereof. Therefore, it can be assumed that the selected research sample is a miniature of the population of students of economics in Poland.

The research included:

1) a number of students trading stocks (WSE), forex and a poker in the past, currently and in the future,

2) finding the interest rate trend of WSE, forex and a poker,

3) the source of information about a specific market,

4) the opinions about WSE, forex and a poker trading, including:
a) a theoretical and practical knowledge that is necessary for a trading activity,
b) a level of commissions and other costs,
c) a quality and a usability of the trading platforms,
d) a level and a way of taxation,
e) a correlation with the general economic situation,
f) an usage of the leverage,
g) trading hours,
h) legal aspects of trading (a poker only).

\section{The results of empirical research and discussion}

Among the students of the last semester of the economics fields (finance, management and economics), 32.3\% (198 out of 613 researched people) are interested in the investments on the financial markets. Such a percentage of interest is surprisingly low, especially if one takes into consideration the field of the studies, widespread promotions of financial markets, easy market access with a low entry-level of the capital. Moreover, the interest is treated very widely and generally - not only real traders are accounted, but also demo traders and just the theoretical interest in the investments (without having the demo or real trading accounts) of real traders - traders having real accounts with real money ${ }^{2}$. Table 2 presents the results of the research - mainly the opinions of the people who are interested in the market activity -198 people (100\%).

2 Real traders - traders having real accounts with real money. 
Table 2. A real and demo experience of trading

\begin{tabular}{|c|c|c|}
\hline Most popular trading activities & $\begin{array}{l}\text { \# of students } \\
\text { per activity* }\end{array}$ & $\%$ (of 198 students) \\
\hline 1. Demo FX only & 40 & $20.2 \%$ \\
\hline 2. Real poker only & 12 & $6.1 \%$ \\
\hline 3. Demo poker only & 9 & $4.5 \%$ \\
\hline 4. Real WSE only & 8 & $4.0 \%$ \\
\hline 5. Demo WSE only & 7 & $3.5 \%$ \\
\hline 6. Real FX only & 6 & $3.0 \%$ \\
\hline 7. Real poker + demo FX & 5 & $2.5 \%$ \\
\hline 8. Real WSE + real FX + real poker & 4 & $2.0 \%$ \\
\hline 9. Real poker + demo WSE + demo FX & 4 & $2.0 \%$ \\
\hline 10. Real WSE + real FX & 3 & $1.5 \%$ \\
\hline 11. Real WSE + demo FX & 3 & $1.5 \%$ \\
\hline 12. Real WSE + demo FX + demo poker & 3 & $1.5 \%$ \\
\hline 13. Real WSE + demo FX + real poker & 2 & $1.0 \%$ \\
\hline 14. Real FX + demo WSE & 2 & $1.0 \%$ \\
\hline 15. Real WSE + demo poker & 1 & $0.5 \%$ \\
\hline 16. Real FX + demo poker & 1 & $0.5 \%$ \\
\hline 17. Real poker + demo WSE & 1 & $0.5 \%$ \\
\hline 18. Real WSE + real poker & 0 & $0.0 \%$ \\
\hline 19. Real WSE + real FX + demo poker & 0 & $0.0 \%$ \\
\hline 20. Real FX + real poker & 0 & $0.0 \%$ \\
\hline 21. Real FX + demo WSE + demo poker & 0 & $0.0 \%$ \\
\hline 22. Real FX + demo WSE + real poker & 0 & $0.0 \%$ \\
\hline Total & 111 & $56.1 \%$ \\
\hline $\begin{array}{c}\text { Most popular markets } \\
\text { (cumulated trading activity) }\end{array}$ & $\begin{array}{l}\text { \# of students } \\
\text { per market** }\end{array}$ & $\%$ (of 198 students) \\
\hline 1. Demo FX & 57 & $28.8 \%$ \\
\hline 2. Real poker & 28 & $14.1 \%$ \\
\hline 3. Real WSE & 24 & $12.1 \%$ \\
\hline 4. Real FX & 16 & $8.1 \%$ \\
\hline 5. Demo WSE & 14 & $7.1 \%$ \\
\hline 6. Demo poker & 14 & $7.1 \%$ \\
\hline
\end{tabular}

* Students with unique combination of activities.

** Cumulated number of students who are active on specific market (students from one market can be active also on the other market).

Note: WSE - Warsaw Stock Exchange, FX - forex

In general, 111 students have or had some trading experience, including real and demo trading on the stock exchange, FX and a poker. The most popular activity among students is forex on the demo accounts (20.2\%), which is quite clear due to the common usage of demo accounts during classes and workshops 
at the university. The second most popular activity is a real poker playing $(6.1 \%)$ and the third - a demo poker playing (4.5\%). Positions 4. to 6 . belong to the WSE and forex, both demo and real accounts.

Surprisingly, combining different activities of investments is very rare. Real trading on two or three markets is realised by only $1-2 \%$ of students. Similar results concern a combination of a real trading on one market and a demo trading on the other ones.

$28.8 \%$ of students tried their trading on demo forex accounts and this result is much stronger than the WSE and poker demo accounts (7.1\%). These proportions were easy to predict due to sophisticated forex trading platforms which perfectly simulate market conditions, including live data streaming and advanced analytical tools and everything is free of charge for an unlimited time. However, students' real capital is usually involved in a poker $(14.1 \%)$ and financial instruments on the WSE (12.1\%). The reason for a poker domination is explained by low starting deposits as well as previous entertaining experiences. The WSE is associated with long term investments and a tolerable stability. Trading on forex is commonly perceived as hard and demanding. High leverage leads to fast and large losses. This is why forex on real accounts is less popular (8.1\%).

The lowest interest is in the WSE and poker demo accounts. Any demonstration platforms of the WSE are rather educative for beginners only. They are underdeveloped, having no live data streaming or analytical tools. In a poker, demo-platforms are unpopular due to the main feature of this game - there is no poker without real money.

Further research was focused on the trading plans for the future among students and their perception of the character of the markets.

One of the most important pieces of information obtained is the perspective of a trading activity. Half of the real WSE investors are going to continue their investments and this is the most pessimistic result. $57.1 \%$ of real poker players and $62.5 \%$ of real forex traders are willing to conduct their activity in the future. What is interesting, in the group of demo traders the distribution is reversed: three fourths of the WSE demo traders, half of forex demo traders and $43.8 \%$ of poker demo players are going to start activities with real money. However, it should be emphasised that students of the economics are very often obliged to make some demo-deals on the financial markets (WSE or forex) as a part of the classes of some lectures (what is confirmed by indicating the lecturers as a source of knowledge about financial markets). As the forex demo-platforms are the best tool for simulating the market conditions, the currency market is the 
most widely chosen to use for lecture purposes. Despite some forced experience on the forex market, the majority of the students are not going to try their hands at real trading.

People without trading experience express their interest rather in the WSE (44.9\% of the students interested in trading, i.e. 198 students) than in the forex $(29.8 \%)$ and a poker (18.7\%). It is not surprising because interest in financial markets is not only a trading, but also a general interest in the economy. In this context, a poker has no connection with the economy and a poker without money is just entertainment. Among people who express their interest in financial markets, two-thirds is going to risk their real money on the stock exchange, onethird on the forex and a quarter on a poker. However, interest in trading activity is not confirmed by the statistics. We assume that the WSE does not use its potential to activate people interested in markets to try trading in real life. Expectations may not match the reality and this forces the potential investors to migrate from the WSE to forex and poker.

It should be mentioned that a poker in Poland via the Internet is legally prohibited due to its classification as a gambling. For $35 \%$ of the researched real poker players the legal issue does not matter, for $60 \%$ of them - it is ethically problematic, but they claim it should be fully legitimate (and they want to pay taxes), and only $5 \%$ of players withdrew their funds due to legal aspects.

The students usually collect information about investment activity themselves - especially of a poker (half of them) and the WSE (41.5\%). In this category, the forex is quite specific - only $19.6 \%$ of students got interested in this type of a trading on their own. Universities play an important role in encouraging financial market activities. For students interested in a trading (the group of 198 students), the university was the source of information about the WSE (39\%), the forex $(55.4 \%)$ and a poker $(13.7 \%$; poker in more likely to be encouraged by friends and families $-35.3 \%$ ).

The functioning of the markets is usually positively assessed. The market parameters, e.g. a liquidity, a quality of the platforms, costs of trading, a taxation, trading hours, which are crucial for experienced traders, do not determine the market choice among the students. The liquidity is seen as sufficient, platforms as useful enough and commissions as acceptable (however, high commissions of the WSE are quite often pointed out as a disadvantage). Taxation and trading hours have marginal importance. 


\section{Conclusions}

This study has contributed in the light of the literature on looking for the reasons of lack of interest in investing among individuals.

Based on the analysed characteristics of investments on the WSE, the forex and a possibility of earning money in a poker game as well as after conducting empirical research, we conclude:

The current market situation does not constitute favourable conditions to increase the commitment of individual investors on the WSE.

The important reason for low share of individual investors in the capital market is an unsatisfactory (decreasing) efficiency and an investment attractiveness of the domestic stock exchange, influencing the decreasing market reliability, which has still not recovered in Poland since the world financial crisis.

The presented results of research have confirmed the low and unsatisfactory activity of individual investors on the WSE. Taking into consideration the statistics covering a longer period, decreasing share and falling number of individual investors on the WSE reflect the serious situation which should be the subject of further analysis and discussion.

Another reason for that situation is a low rate of a financial literacy of the Polish society and no firm actions in the area of a formal financial education. Limited knowledge and very basic financial abilities prevent interest in a trading, which is usually the initial stage of any choices in the area of markets.

The important alternatives to investment on the WSE for young people are both the forex as well as... a poker game, but there is still a potential for increasing investment on the WSE by youth.

The research limitation is the fact that the study only concerns the Polish students, but the target study group will be expanded in future research.

However, the conducted research has shown some potential, which refers to people open to investments of higher risk and constitutes a chance to improve the activity of individual investors on the WSE. One of the possibilities is to increase the interest in trading among young people, especially those who have the best education in the field of economics. Among them, there is visible potential which might be utilised by the WSE. In particular, it refers to students of economic faculties, interested in the investments of higher risk, who have not made any real transactions yet. Definitely, the more challenging task is to 'move' investors from the forex to the WSE. It seems more probable to attract successfully poker players instead. 
Finally, the importance of higher effectiveness of the financial education among the potential participants of financial markets should be emphasised. In practice, the cooperation of universities and the WSE should be considered. The students of economics might promote the financial market and its separate segments as reliable and trustworthy experts in the future.

\section{References}

Aravind, M. (2017). FX volatility impact on Indian Stock Market: An empirical investigation. The Journal of Business Perspective, 21(3), 284-294. https://doi.org/10. $1177 / 0972262917716760$

Aren, S., \& Aydemir, D. (2015). The factors influencing given investment choices of individuals. Procedia - Social and Behavioral Sciences, 210, 126-135. https://doi. org/10.1016/j.sbspro.2015.11.351

Arthur, J. N., Williams, R. J., \& Delfabbro, P. H. (2016). The conceptual and empirical relationship between gambling, investing, and speculation. Journal of Behavioral Addictions, 5(4), 580-591. https://doi: 10.1556/2006.5.2016.084

Aruna, P., \& Rajashekar, H. (2016). Factors influencing investment decisions of retail investors - a descriptive study. International Journal of Business and Management Invention, 5(12), 6-9. Retrieved September 23, 2019 from https://www.ijbmi.org/ papers/Vol(5)12/version-2/B512020609.pdf

Australian Securities Exchange. (2012). Australian share ownership study. Retrieved April 3, 2019 from https://www.asx.com.au/documents/resources/asx-sos-2012.pdf

Baker, M., \& Wurgler, J. (2007). Investor sentiment in the stock market. Journal of Economic Perspectives, 21(2), 129-152. https://doi.org/10.2139/ssrn.962706

Bank for International Settlements. (2016). Triennial Central Bank survey foreign exchange turnover in April 2016. Monetary and Economic Department. Retrieved April 3, 2019 from http://www.bis.org/publ/rpfx16fx.pdf

Barasinska, N., \& Schäfer, D. (2018). Gender role asymmetry and stock market participation - evidence from four European household surveys. The European Journal of Finance, 24(12), 1026-1046. https://doi.org/10.1080/1351847X.2017.1371622

Bartkiewicz, P., \& Łęcki, M. (2015). GPW w Warszawie - równia pochyła [Warsaw Stock Exchange - the inclined plane]. Zeszyty Naukowe Uniwersytetu Szczecińskiego. Finanse, Rynki Finansowe, Ubezpieczenia, 74(855), 1, 11-22. https://doi: 10.18276/frfu.2015.74/1-01

Bennet, E., Selvam, M., Indhumathi, G., Ramkumar, R. R., \& Karpagam, V. (2011). Factors influencing retail investors' attitude towards investing in equity stocks: A study in Tamil Nadu. Journal of Modern Accounting and Auditing, 7(3), 316-321. Retrieved April 3, 2019 from https://docplayer.net/15286306-Factors-influencing-retailinvestors-attitude-towards-investing-in-equity-stocks-a-study-in-tamil-nadu.html 
Brown, A. (2006). The poker face of Wall Street. Hoboken, New Jersey: Wiley \& Sons.

CFA Institute. (2016). What investors want a global survey of 2016. Retrieved April 3, 2019 from https://www.cfainstitute.org/en/research/survey-reports/from-trust-to-loyalty

Christiansen, Ch., Joensen, J. S., \& Rangvid, J. (2008). Are economists more likely to hold stocks? Review of Finance, 12(3), 465-496. https://doi.org/10.1093/rof/rfm026

Dąbrowski, P. (2014). The level of Warsaw Stock Exchange commissions as a shortterm trading impediment. Journal of Economics and Management, 16, 17-26. Retrieved April 3, 2019 from https://www.ue.katowice.pl/fileadmin/user_upload/ wydawnictwo/JEM_Artyku\%C5\%82y_1_30/JEM_16/02.pdf

Deloitte Access Economics. (2017). ASX Australian Investor Study 2017. Retrieved April 3, 2019 from https://www.asx.com.au/documents/resources/2017-asx-investorstudy.pdf

DiCicco-Bloom, B., \& Romer, D. (2012). Poker, sports betting, and less popular alternatives: Status, friendship networks, and male adolescent gambling. Youth \& Society, 44 (1), 141-170. https://doi.org/10.1177/0044118X10396641

Evans, A. (2016). A requiem form the retail investor? University of Michigan Law School Scholarship Repository. Retrieved April 3, 2019 from http://repository. law.umich.edu/cgi/viewcontent.cgi?article $=1117 \&$ context $=$ articles

Financial portal Stooq.pl. (s.a.). Retrieved July 7, 2019 from https://stooq.pl

Felix, D., \& Reis, L. P. (2008a). An experimental approach to online opponent modeling in Texas Hold'em Poker. In 19th Brazilian Symposium on Artificial Intelligence: Advances in Artificial Intelligence, Savador, Brazil (pp. 83-92). Berlin: Springer Verlag.

Félix, D., \& Reis, L. P. (2008b). Opponent modelling in Texas Hold'em Poker as the key for success. In ECAI 2008: 18th European Conference on Artificial Intelligence, Amsterdam, The Netherlands (pp. 893-894). Amsterdam: IOS Press.

Frączek, B. (2016). Iluzja wiedzy finansowej jako zagrożenie dla zwiększenia stopnia włączenia finansowego i funkcjonowania rynku finansowego [The illusion of knowledge as a threat to increasing the degree of a financial inclusion and a functioning of the financial market]. In T. Czerwińska \& A. Z. Nowak (eds.), Rynek kapitałowy - efektywność i ryzyko [Capital market - efficiency and risk] (pp. 2739). Warszawa: Wydawnictwo Uniwersytetu Warszawskiego.

Frączek, B., Bobenič Hintošová, A., Bačová, M., \& Siviček, T. (2017). Simultaneous use of the financial literacy level and the financial inclusion degree as a result of financial education efficiency in Visegrad Group Countries. Journal of Economics \& Management, 27(1), 5-25. https://doi: 10.22367/jem.2017.27.01

Geetha, S. N., \& Vimala, K. (2014). Perception of household individual investors towards selected financial investment avenues. Procedia Economics and Finance, 11, 360-374. https://doi.org/10.1016/S2212-5671(14)00204-4

Goodfellow, C., Bohl, M. T., \& Gebka, B. (2009). Together we invest? Individual and institutional investors' trading behaviour in Poland. International Review of Financial Analysis, 18, 212-221. https://doi.org/10.1016/j.irfa.2009.03.002 
Grall-Bronnecab, M., Sauvagetac, A., Boutind, C., Bulteaua, S., Jiménez-Murciace, S., Fernández-Arandace, F., Challet-Boujuab, G., \& Caillona, J. (2017). Excessive trading, a gambling disorder in its own right? A case study on a French disordered gamblers cohort. Addictive Behaviors, 64, 340-348. https://doi: 10.1016/j.addbeh. 2015.12.006

Hong Kong Exchanges and Clearing Limited. (2015). Retail Investors Survey 2014. Retrieved from https://www.hkex.com.hk/eng/stat/research/Documents/RIS2014.pdf

Hong Kong Investors Survey. (2000, 2004, 2005, 2007, 2009, 2010). Retail Investors Surveys. Retrieved April 1, 2019 from https://www.hkex.com.hk/News/ResearchReports/HKEX-Surveys/HKEX-Surveys?sc_lang=en

Hunter, A., \& Griffiths, M. D. (2012). What differentiates professional poker players from recreational poker players? A qualitative interview study. International Journal of Mental Health and Addiction, 10(2), 243-257. https://doi.org/10.1007/s11 469-011-9312-y

Investor Education Centre. (2017). Retail Investor Study Research Report (A research commissioned by the Investor Education Centre and conducted by GfK Hong Kong). Retrieved April 3, 2019 from https://www.thechinfamily.hk/web/common /pdf/about_iec/IEC-Retail-Investor-Study-report.pdf

Jadlow, J. W., \& Mowen, J. C. (2010). Comparing the traits of stock market investors and gamblers. Journal of Behavioral Finance, 11(2), 67-81. https://doi.org/10.1080 $/ 15427560.2010 .481978$

Joshi, M. C., \& Batra, Y. (2017). Factors affecting investment decision in stock market. In S. L. S. Akoijam, N. Panchal, \& W. C. Singh (eds.), Business and competitive advantage: Creating and sustaining ideas to solve contemporary issues in recent era (pp. 204-209). New Delhi: Ruby Press \& Co..

Kim, H. S., Wohl, M. J. A., Gupta, R., \& Derevensky, J. L. (2017). Why do young adults gamble online? A qualitative study of motivations to transition from social casino games to online gambling. Asian Journal of Gambling Issues and Public Health, 7(1), article number: 6. https://doi: 10.1186/s40405-017-0025-4

Kiran, D., \& Rao, U. S. (2005). Identifying investor group segments based on demographic and psychographic characteristics. Paper presented at 8th Capital Markets Conference, Indian Institute of Capital Markets Paper, 1-9. https://doi.org/10. 2139/ssrn.870749

KNF - Polish Financial Supervision Authority. (s.a.). Retrieved July 1, 2019 from https://www.knf.gov.pl/knf/pl/komponenty/img/Komunikat_UKNF_nt_wynikow_ klientow_na_rynku_Forex_2019_65254.pdf

Kourtidis, D., Ševic, Ž., \& Chatzoglou, P. (2011). Investors' trading activity: A behavioral perspective and empirical results. The Journal of Socio-Economics, 40, 548-557. https://doi.org/10.1016/j.socec.2011.04.008

Kumari, A., Satya, P., \& Kritika (2018). Factors affecting saving and investment behavior of the teachers. International Journal of Current Microbiology and Applied Sciences, 7(6), 278-281. https://doi.org/10.20546/ijcmas.2018.706.032 
Levitt, S. D., \& Miles, T. J. (2011). The role of skill versus luck in poker: Evidence from the World Series of Poker (NBER Working Paper, No. 17023). Retrieved April 15, 2019 from https://www.nber.org/papers/w17023.pdf

Levitt, S. D., \& Miles, T. J. (2014). The role of skill versus luck in poker evidence from the world series of poker. Journal of Sports Economics, 15(1), 31-44. https:// doi.org/10.1177/1527002512449471

Lodhi, S. (2014). Factors influencing individual investor behaviour: An empirical study of city Karachi. Journal of Business and Management, 16(2), 68-76. doi: 10.9790/ 487X-16236876

Loon, R. J. D. P., Assem, M., \& Dolder, D. (2015). Beyond chance? The persistence of performance in online poker. PLoS One, 10(3), e0115479. https://doi: 0.1371/ journal.pone.0115479

Markiewicz, Ł., \& Weber, E. U. (2013). DOSPERT's gambling risk-taking propensity scale predicts excessive stock trading. Journal of Behavioral Finance, 14, 65-78. https://doi.org/10.1080/15427560.2013.762000

Männikkö, N. (2017). Problematic gaming behavior among adolescents and young adults (Acta Universitatis Ouluensis, D Medica 429). Oulu: University of Oulu. Retrieved April 3, 2019 from http://Jultika.Oulu.Fi/Files/Isbn9789526216584.Pdf

Messerlian, C., Byrne, A., \& Derevensky, J. (2004). Gambling, youth and the internet: Should we be concerned? Journal of the Canadian Academy of Child and Adolescent Psychiatry, 13(1), 3-6. Retrieved April 3, 2019 from https://www.ncbi. nlm.nih.gov/pmc/articles/PMC2533814/

Meyer, G., Meduna, M., Brosowski, T., \& Hayer, T. (2012). Is poker a game of skill or chance? A quasi-experimental study. Journal of Gambling Behavior, 29(3), https:// doi: $10.1007 /$ s10899-012-9327-8

Moreau, A., Chabrol, H., \& Chauchard, E. (2016). Psychopathology of online poker players: Review of literature. Journal of Behavioral Addictions, 5(2), 155-168. https://doi: 10.1556/2006.5.2016.035

Nagy, R. A., \& Obenberger, R. W. (1994, reprints 2018). Factors influencing individual investor behaviour. Financial Analysts Journal, 50(4), 63-68. https://doi.org/10. 2469/faj.v50.n4.63

Nguyen, C., \& Bhatti, M. I. (2015). Investor sentiment and idiosyncratic volatility puzzle: Evidence from the Chinese Stock Market. Journal of Stock \& Forex Trading, 4(3), https://doi:10.4172/2168-9458.1000158

Obamuyi, T. M. (2013). Factors influencing investment decisions in capital market: A study of individual investors in Nigeria. Organizations and Markets in Emerging Economies, 4(7), 141-161. Retrieved October 10, 2019 from https://EconPapers. repec.org/RePEc:vul:omefvu:v:4:y:2013:i:1:id:147

Palomäki, J. (2013). New perspectives on emotional processes and decision making in the game of poker. Cognitive Science, Institute of Behavioural Sciences, University of Helsinki, Finland. Retrieved April 3, 2019 from https://helda.helsinki.fi/ handle/10138/41569 
Seetharaman, A. I. Niranjan, I., Patwa, N., \& Kejriwal, A. (2017). A study of the factors affecting the choice of investment portfolio by individual investors in Singapore. Accounting and Finance Research, 6(3), 153-168. https://doi.org/10.5430/afr.v6n3P153

Shanmugham, R., \& Ramya, K. (2012). Impact of social factors on individual investors' trading behaviour. Procedia Economics and Finance, 2, 237-246. https://doi.org /10.1016/S2212-5671(12)00084-6

Wierzbicka, A. (2016). Rola inwestorów w rozwoju nadzoru korporacyjnego [The role of investors in the development of corporate governance]. Studia Ekonomiczne. Zeszyty Naukowe Uniwersytetu Ekonomicznego w Katowicach, 263, 179-189. Retrieved July 1, 2019 from http://cejsh.icm.edu.pl/cejsh/element/bwmeta1.element. cejsh-2e5aa7cf-68ab-41ae-8581-14e076e404f7

WSE. (2018). Analysis - investor share in trading. Retrieved April 1, 2019 from https:// www.gpw.pl/analysis-investor-share-in-trading 